\section{Pre-admission Investigations}

SIR,-I presume that hospital case summaries are frequently used for research purposes and should therefore be as accurate as possible.

During 20 years in general practice it has struck me as very odd that according to these summaries the patient's investigations and specific treatment nearly always start on his admission to hospital or attendance at the outpatient department. There is rarely any reference to investigations done by the general practitioner before the patient came under the care of the hospital. Yet with open access to $x$-ray and laboratory facilities considerable information may have been obtained concerning the patient's illness before referral to a hospital consultant. The case summaries also give the impression that a considerable time has elapsed between the patient presenting his symptoms to the G.P. and his subsequent referral to hospital, without the G.P. doing anything positive.

All this enhances the impression that all "real" medicine takes place in hospital and that the G.P. is just a referring agent. I think that it is about time that this impression was corrected and that case summaries should give credit to the G.P. where it is due.-I am, etc.,

BERNARd TAYLOR

Chairman, Education Committee, Royal College of General Practitioners

London E.3

\section{Orthopaedic Trauma and Plasma Lipids}

SIR,-O'Driscoll and Powell ${ }^{1}$ found raised serum lipid levels in patients after orthopaedic surgery, particularly on the third postoperative day, and after serious injury, and in both types of case they studied the lipid-lowering action of clofibrate. In a study of nine patients undergoing orthopaedic operations-six cases of total hip-joint prostheses and three of subtrochanteric osteotomy-we found that the serum lipid levels decreased, and we report our findings here.

Blood samples were collected on an empty stomach before operation and on the second, fourth, and sixth postoperative days. Total lipids were extracted from plasma, stored fats, and bone marrow samples and purified and measured. ${ }^{2}$ Total cholesterol, ${ }^{3}$ phospholipids, ${ }^{4}$ triglycerides and free fatty acids, ${ }^{5}$ and total fatty acids (by gas liquid chromatography ${ }^{6}$ ) in the purified lipid extract were determined. Total plasma lipids, phospholipids, triglycerides, and total cholesterol were all decreased, reaching their lowest levels on the second and fourth postoperative day, but they tended to increase slightly on the sixth postoperative day. Plasma free fatty acids decreased progressively on the second, fourth, and sixth postoperative day (see fig.).

These findings showed that plasma lipids did not increase in these patients after orthopaedic surgery and that there was no detectable reabsorption of stored subcutaneous or bone marrow lipid. Oleic acid $53 \%$ of which is in bone marrow and stored subcutaneous fats and $31 \%$ in plasma, did not increase in the plasma, whereas arachidonic acid, less than $1 \%$ of which is in bone marrow and stored subcutaneous fats and $5-6 \%$ in plasma, increased slightly in the plasma. Triglycerides, over $97 \%$ of which are in bone marrow and in stored subcutaneous fats, also decreased in the plasma.

The decrease in plasma lipids in our patients during the first four postoperative days is consistent with that reported by Wadström, ${ }^{7}$ and was probably due to the fact that the patients ate little after the

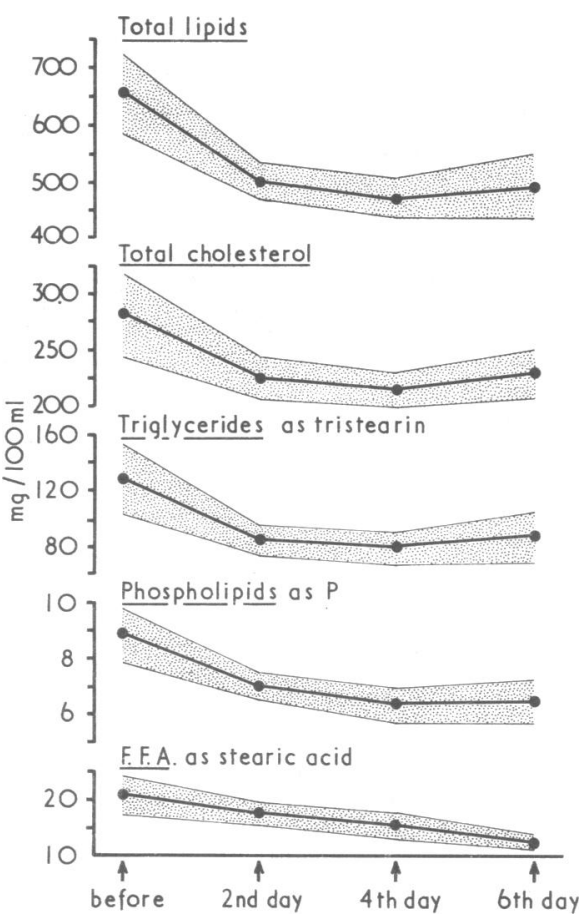

operation. Recently McNamara and colleagues $^{8}$ studied serum lipids in cases of surgery for war wounds. The cases were divided into four groups, according to the seriousness of the injuries, and in all four groups plasma lipids either decreased or remained constant.

These findings differ from those of O'Driscoll and Powell, and we think therefore that patients with orthopaedic trauma are unsuitable for use in experiments aimed at studying lipid-lowering drugs.-We are, etc.,

Simes di Cardiologia Sperimentale,

GHIRARD A. MARZO

Centro Ortopedico Traumatologico,

F. Muzz

Milan, Italy

1 O'Driscoll, M., and Powell, F. J., British Medical foumal, 1967, 4, 149.

Folch, J., Lees, M., and Sloane, G. H., fournal of Biological Chemistry, 1957, 226, 497

Vanzetti, G., and Gatti, E., Biochimica Applicata, $1963,10,34$.

Allen, R. J. L., Biochemical fournal, 1940, 34, 858 G., Clinical Chemistry, 1971, 17, 145. Böttcher, C. J. F., Woodford, F. P., Boelsma-van Houte, E., and Van Gent, C. M., Recueil des Belgique, 1959, 78, 794.

7 Wadstróm, B. L., Acta Chirurgica Scandinavica Suppl., 1959, 238.

McNamara, J. J., Molot, M., Dunn, R., Burran E. L., and Stremple, J. F., Fournal of Thoracic and Cardiovascular Surgery, 1972, 63, 968.

\section{Sickle-cell Anaemia}

SIR,-With reference to Colonel H. Gall's query (24 February, p. 488), it is probable that sickle-cell anaemia was known to medicine long before Herrick's classic description in 1910, although it was not called by that name as the pathogenesis remained obscure until peripheral blood-smear examination came into use. Indeed, suggestive clinical and pathological evidence of sicklecell anaemia before 1905 was well documented as far back as 1846 according to Serjeant and Serjeant. ${ }^{1}$

The characteristic finding in all cases is "autosplenectomy," the phenomenon of a previously large spleen becoming small and non-palpable in later years, a clinical finding which seems to be unique to sickle-cell anaemia. ${ }^{3}$ At necropsy the pathology of the spleen is that of a gritty, fibrous remnant. Its identification would require at least a knowledge of the natural history of the spleen in this condition, and thorough scrutiny.-I am, etc.,

I. MAMMAN

Lambeth Hospital,

London S.E.11

1 Serieant, G., and Serieant, B., Lancet, 1972, 1

Lehmann, H., and Huntsman, R. G., Man's Haemoglobins, p. 107. Amsterdam, NorthHolland Publishing Co., 1966.

Maegraith, B. G., Adams and Maegraith. Clinical Tropical Diseases, 5th edn., p. 126. Oxford, Blackwell, 1971

Edington, G. M., and Gilles, H. M. Pathology in the Tropics, p. 378 et seq. London, Arnold,

\section{Löffler's Syndrome}

SIR,-Drs. C. C. Bailey and R. H. A. Campbell (24 February, p. 460) describe the case of a 4-year-old boy suffering from lymphosarcoma which involved the lungs and was associated with marked eosinophilia. I submit that it is incorrect to say that this case presented as Löffler's syndrome.

Löffler, ${ }^{1-4}$ of Zurich, described a series of patients with relatively minor respiratory symptoms and clinical signs, pulmonary radiological opacities which were transient (invariably clearing up in under one month), and an associated eosinophilia which was usually not very pronounced. The condition was, in virtually all cases, due to infestation with Ascaris lumbricoides, which was at that time very prevalent in Switzerland. The term "Löffler's syndrome" now embraces also the transient changes seen in other worm infestations, as well as conditions such as transient pulmonary reactions resulting from various drug allergies.

The case reported by Drs. Bailey and Campbell would have been more accurately described as pulmonary involvement by lymphosarcoma associated with pronounced eosinophilia. The term "Löffler's syndrome" should not be used to describe any and every pulmonary disease associated with eosinophilia. Löffler's syndrome is merely one group of disorders within the broader classification of the pulmonary eosinophilias. -I am, etc.,

Redhill General Hospital,

Alex Sakula

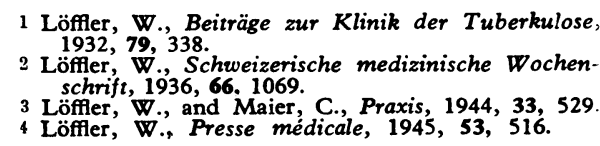

\section{Prescribing Mandrax}

SIR,-My admiration of medical men who choose the administrative side of medicine to work in rather than attempt to apply their art and skill to their fellow men has never 